\title{
EFFECT OF CHICKEN MANURE COMBINED WITH BIO-FERTILIZERS, MINERAL FERTILIZER AND SOME FOLIAR APPLICATIONS ON: 1- VEGETATIVE GROWTH AND SOME CHEMICAL CONSTITUENTS OF TOMATO LEAVES.
}

Dawa, Kawsar k. A. ; T. M. Al-Gazar and A. M. Abdel-Fatah

Vege. \& Flori. Dept., Faculty of Agriculture, Mansoura University. Egypt.

\begin{abstract}
Two successive field experiments were conducted in a private farm at Gemiana village near El-Mansoura city, Dakahlia Government, Egypt, during seasons of 2009 and 2010 to evaluate the effect of two rates of chicken manure combined with bio-fertilizers, mineral fertilizers and some foliar application treatments as well as their interactions on vegetative growth parameters (Plant height, No. of branches/plant, No. of leaves/plant, Fresh and Dry weights)and some chemical constitutes of tomato leaves (Lycopersicon esculentum) "Nada" hybrid under drip irrigation system.

The obtained results showed that the mean values of plant height, number of leaves and branches/plant, fresh and dry weights of tomato plants, N, P, K\% in the leaves, chlorophyll $\mathrm{a}, \mathrm{b}$ and total chlorophyll were increased due to increasing chicken manure rate up to 6 ton/fed. + bio fertilizer mixture during both seasons of the experimentation. Also, the highest mean values of vegetative growth parameters, N, $P$ and $\mathrm{K}$ percentages, chlorophyll $\mathrm{a}, \mathrm{b}$ and total chlorophyll in leaves under study were obtained with increasing NPK level from 0 up to $50 \%$ of the recommended dose (RD) during both seasons.

The highest significant values of the aforementioned parameters were recorded with spraying plants by seaweed extract $(2.5 \mathrm{ml} / \mathrm{L}$.) followed by spraying yeast extract $(5 \mathrm{~g} / \mathrm{L}$.). These increases were true in the two seasons of the study.

The study showed that the best results of vegetative growth parameters and N, P and $\mathrm{K}$ percentages in the leaves, chlorophyll $\mathrm{a}, \mathrm{b}$ and total chlorophyll were recorded with adding 6 ton/fed. chicken manure + bio fertilizer mixture with 50\% NPK from
\end{abstract} recommended dose and spraying seaweed extract during both seasons.

Keywords: Tomato, chicken manure, mineral fertilization, bio-fertilization, seaweed, yeast.

\section{INTRODUCTION}

Tomato is one of the most important vegetable crops in the world. The tomato belongs to the family Solanaceae, genus Lycopersicon, which contain some important minerals, vitamins. Tomatoes are now eaten freely throughout the world, and their consumption is believed to benefit the heart among other things. Tomato is considered the most vegetable crop in Egypt. Among the methods followed for improving the quantity and quality of tomato fruits are the application of major fertilizers to satisfy the needs of plants from such elements since good growth is mostly associated with good yield and best quality.

In this respect, several investigators carried out a lot of trials. For example, Malak et al. (2008) studied the effect of poultry manure and mineral 
Dawa, Kawsar k. A. et al.

fertilizers on vegetative growth of tomato, the vegetative growth parameters were increased by increasing fertilizer levels in the two seasons.

Ayeni et al. (2010) illustrated that poultry manure at 20, 30 and $40 \mathrm{t}$ ha $^{-1}$ and NPK 15:15:15 fertilizer significantly increased plant leaf area, plant height, number of leaves and branches of tomato plant. Mahila et al. (2010) studied the effects of organic, mineral and bio- $\mathrm{N}$-fertilizers on growth and productivity of tomato plants (Lycopersicon esculentum Mill) grown in greenhouse. The results indicated that applying organic manure (chicken manure in high rate) combined with bio- $\mathrm{N}$ fertilizer (rhizobacteria) and mineral- $\mathrm{N}$ fertilisers gave the vigorous plants expressed as plant length, number of leaves and stems as well as shoots dry weight in both seasons. ElSherif (2006) obtained the highest $\mathrm{N}$ and $\mathrm{K}$ percentages as well as total chlorophyll in cucumber leaves grown in higher addition of organic manure (6 ton/fed.) compared to 2 and 4 ton/fed. Moreover, Ewulo et al. (2008) illustrated that $\mathrm{N}, \mathrm{P}$ and $\mathrm{K}$ content were increased with the increase in the level of chicken manure up to $30 \mathrm{t} \mathrm{ha}^{-1}$. There is a great debate among scientists about the role played by microorganisms in promoting plant growth, while some other investigators directed their contribution to N2-fixation, P or $\mathrm{K}$ solubilization, cellulose decomposition, etc. Others went to production of plant growth modifying substances by such bio-fertilizers. Many investigators reported that application of Bio-fertilizer affected positively plant growth of tomato. Fawzy et al. (2007) found that inoculation tomato plants with nitrobin (Azotobacter and Azospirillum) recorded a significant increases in the vegetative growth parameters. Mahato et al. (2009) showed that the maximum number of seedling emergence, shoot length and number of leaves were recorded for the plants treated with Azotobacter in comparison to the uninoculated plants. Turan et al. (2007) found that phosphorus solubilizing bacteria decreased soil $\mathrm{pH}$, increased availability and uptake of phosphorus and improved growth and dry mass of tomato plants. They also added that to maximize phosphorus fertilizers efficiency and improve growth, mineral composition and productivity of tomato, it was suggested to apply Pfertilization combined with phosphorus dissolving bacteria. El-Said (2009) concluded that the application of superphosphate at $65 \%$ of recommended rate / fed. in the presence of inoculation tomato seedlings with phosphorin showed the most superior significant values of plant height, number of leaves and dry weight per plant. Baddour (2010) stated that increasing NPK- applied level from 50 to $75 \%$ and, furtherly to $100 \%$ RD significantly increased vegetative growth parameters $\mathrm{N}, \mathrm{P}$ and $\mathrm{K} \%$ in the leaves. The highest mean values for the previously mentioned traits were found to be associated with the addition of $100 \%$ RD-NPK. However, Foliar application of yeast extract and seaweed extract on tomato plants increased vegetative growth parameters and $\mathrm{N}, \mathrm{P}$, and $\mathrm{K}$ percentages in leaves as shown by many researchers( El-Sayed et al. , (2010) ; Abou El-Yazied and Mady , (2011)). Also, Dawa et al. (2012) on pepper plant found that foliar application of seaweed extract with chicken manure as a source of organic fertilization in presence of bio fertilizers enhanced vegetative plant growth, N, P and K percentages in leaves. 
The study aimed to evaluate the effect of organic manure + biofertilization, mineral fertilization and some foliar applications on vegetative growth and some chemical constituents of tomato leaves under Egyption conditions.

\section{MATERIALS AND METHODS}

Two successive field experiments were conducted in a private farm at Gemiana village near El-Mansoura city, Dakahlia Government, Egypt, during seasons of 2009 and 2010 to evaluate the effect of two rates of organic manure (chicken manure) combined with bio-fertilizers, mineral fertilizers and some foliar application treatments as well as their interactions on vegetative growth and some chemical constitutes of tomato leaves (Lycopersicon esculentum) "Nada" hybrid under drip irrigation system. Physical and chemical analyses of experimental soil were conducted at Mansoura Center of Soil Improvement, Mansoura.

Some physical and chemical properties of the investigated soil profile of cultivated area ( 0.0 to $30 \mathrm{~cm}$ depth) are given in Table 1.

Table 1: Some physical and chemical properties of the experimental soil during 2009-2010 seasons.

\begin{tabular}{|c|c|c|c|}
\hline \multicolumn{2}{|c|}{ Soil characters } & 2009 & 2010 \\
\hline \multirow{5}{*}{$\begin{array}{l}\text { Mechanical } \\
(\%)\end{array}$} & Coarse sand & 2.18 & 2.20 \\
\hline & Fine sand & 23.05 & 23.10 \\
\hline & Silt & 32.98 & 32.93 \\
\hline & Clay & 41.79 & 41.77 \\
\hline & Texture class & Loamy & Loamy \\
\hline \multicolumn{2}{|c|}{ 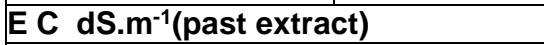 } & 1.07 & 1.09 \\
\hline \multicolumn{2}{|c|}{ pH (paste) } & 8.13 & 8.16 \\
\hline \multicolumn{2}{|c|}{ Saturation percentage (S P \%) } & 51 & 54 \\
\hline \multicolumn{2}{|c|}{ Organic matter (O M \%) } & 1.65 & 1.64 \\
\hline \multicolumn{2}{|c|}{ T. $\mathrm{CaCO}_{3} \%$} & 3.37 & 3.41 \\
\hline \multirow{3}{*}{ Available (mg/kg) } & $\mathbf{N}$ & 48 & 52 \\
\hline & $\mathbf{P}$ & 4.25 & 4.31 \\
\hline & $\mathbf{K}$ & 375 & 379 \\
\hline
\end{tabular}

At mid June during the two seasons of the study, tomato seeds were sown in foam trays with peat and vermiculite $(1: 1)$, enriched with different nutrients, and then seedlings of 45 days old were transplanted into open field at the beginning of August in the two seasons of study.

The experiment included 12 treatments, which were arranged in split-split block design as follows: The main plots were devoted for organic manure (at a rate of $65 \mathrm{~kg} \mathrm{~N} / \mathrm{fed}$. (using chicken manure at 3 ton/fed.) + bio fertilizers and at a rate of $130 \mathrm{~kg} \mathrm{~N} / \mathrm{fed}$. (using chicken manure at 6 ton/fed.) 
Dawa, Kawsar k. A. et al.

+ bio fertilizers mixture), While the sub plots were for the rates of NPK fertilizers at the rates of $0 \& 50 \%$ from the recommended doses for tomato plants, i.e., 75,35 and $85.5 \mathrm{~kg}_{\text {fed }}{ }^{-1}$ for $\mathrm{N}, \mathrm{P}$ and $\mathrm{K}$, respectively. The foliar application treatments were randomly distributed in the sub sub plots using seaweed extract at the rate of $2.5 \mathrm{~m} / \mathrm{l}$., yeast at the rate of $5 \mathrm{~g} / \mathrm{l}$. and tap water). The experimental unit area was $27 \mathrm{~m}^{2}$ it contains one dripper line with $18 \mathrm{~m}$ length and $1.5 \mathrm{~m}$ width. Seedlings were transplanted at spacing $50 \mathrm{~cm}$. Each treatment was replicated three times. Table 2.

Some chemical properties of the used chicken manure are shown in

Table 2: Some chemical properties of the chicken manure used during of 2009 and 2010 seasons.

\begin{tabular}{|c|c|c|c|c|c|c|c|c|c|}
\hline \multicolumn{4}{|c|}{$\%$} & \multicolumn{2}{c|}{$\begin{array}{c}\text { Available } \\
\text { ppm }\end{array}$} & $\begin{array}{c}\text { Saturation } \\
\text { percentage } \\
\%\end{array}$ & $\begin{array}{c}\mathbf{p H} \\
\mathbf{1}\end{array}$ \\
\hline $\begin{array}{c}\text { Organic } \\
\text { matter }\end{array}$ & Carbon & $\begin{array}{c}\text { Total } \\
\mathbf{N}\end{array}$ & $\begin{array}{c}\text { C/N } \\
\text { ratio }\end{array}$ & Total P & Total K & $\mathbf{P}$ & $\mathbf{K}$ & & \\
\hline 56.9 & 33.08 & 2.15 & 15.39 & 0.106 & 0.98 & 3.9 & 985 & 153 & 6.81 \\
\hline
\end{tabular}

The bio-fertilizers involved a mixture of beneficial micro-organisms including Azotobacter chroccocum bacteria which fix nitrogen by a free manner; Bacillus circulans bacteria which make potassium more available and Bacillus megatherium bacteria which increases phosphorus and many nutrients absorption. All inoculants were provided by Bio-fertilizer Unit, Fac. Agric., Ain Shams University.

Bio-fertilizer solution was added to the wet soil twice to the root absorption zone of each plant at the recommended rate $(5 \mathrm{ml} / \mathrm{plant})$, the first one was added 10 days from transplanting. The second one was after 30 days from transplanting.

\section{Mineral fertilizers treatments:}

Hold at the recommended chemical fertilizers for tomato production under drip irrigation system, the used fertilizers were as follows: Nitrogen fertilizer was applied using ammonium nitrate $(33.5 \% \mathrm{~N})$, ammonium sulphate $(20.5 \% \mathrm{~N})$ and calcium nitrate $(15 \% \mathrm{~N})$. Phosphor fertilizer was applied as phosphoric acid $\left(60 \% \mathrm{P}_{2} \mathrm{O}_{5}\right)$. Potassium fertilizer was applied using potassium sulphate $\left(48 \% \mathrm{~K}_{2} \mathrm{O}\right)$. Two treatments of $\mathrm{N}, \mathrm{P}$ and $\mathrm{K}$ fertilizers at the rates of $0 \& 50 \%$ from the recommended doses for tomato plants, i.e., $75 \mathrm{~N}, 35 \mathrm{P}_{2} \mathrm{O}_{5}$ and $85.5 \mathrm{~K}_{2} \mathrm{O} \mathrm{kg.fed}{ }^{-1}$ for $\mathrm{N}, \mathrm{P}$ and $\mathrm{K}$, respectively.

All treatments of mineral fertilization were added as a fertigation through the drip irrigation system.

Foliar application treatments:

Plants were sprayed three times with the different assigned treatments (yeast, seaweed and tap water) starting after 30 days from transplanting and repeated after 15 days from the last one.

During the growing seasons, all agricultural practices were performed according to the ministry of agriculture and land reclamation recommendations. 
Nine plants were randomly taken from each treatment after 75 days from transplanting) during both seasons and the vegetative growth parameters were measured in expression of Plant height $(\mathrm{cm})$, No. of branches/plant, No. of leaves/plant and fresh weight ( $\mathrm{g} /$ plant) of plant folige.

Plant samples were oven dried at $70^{\circ} \mathrm{C}$ tell constant weight was reached, and then dry weight in gm per plant was calculated. The dried plant samples were thoroughly ground and stored for chemical analysis. Chemical analysis in leaves was N, P K and chlorophyll ( $\mathrm{a}, \mathrm{b}$ and total chlorophyll).

\section{Plant Analysis:}

Total $\mathrm{N}, \mathrm{P}$ and $\mathrm{K} \%$ were determined in the digested plant materials using the methods of Pregle 1945, Jackson 1967, Black 1965 and Chapman and Pratt (1961).

Chlorophyll content was estimated as the method described by Goodwine (1965)

All data were statistically analyzed according to the technique of analysis variance (ANOVA) and the least significant difference ( $L S$ D) method was used to compare the deference between the means of treatment values to the methods described by Gomez and Gomez, (1984). All statistical analyses were performed using analysis of variance technique by means of CoSTATE Computer Software.

\section{RESULTS AND DISCUSSION}

\section{Vegetative growth parameters:}

Data of vegetative growth parameters, i.e., plant height $(\mathrm{cm})$, number of leaves and branches/plant, fresh and dry weight ( $\mathrm{g} / \mathrm{plant}$ ) of tomato plants as affected by chicken manure + bio mixture, mineral fertilization and foliar application treatments are presented in Table 3.

\section{Effect of chicken manure + bio mixture:}

Concerning the effect of adding chicken manure + bio mixture, data in Table 3 reveal that the mean values of plant height, number of leaves and branches/plant, fresh and dry weights of tomato plants were significantly increased due to increasing chicken manure rate up to 6 ton/fed. + bio mixture during both seasons of the experimentation except the average values of number of branches/plant in the $1^{\text {st }}$ season. Increases in the vegetative growth of tomato plants by applying chicken manure might be referred to its role in enhancing soil physical prosperities as soil texture, water holding capacity and it creates good aeration in soils and decreased the $\mathrm{pH}$ value and consequently nutrients in the soil became more available for enhancing plant growth. This result is in agreement with Togun and Akanbi (2003), Adenawoola and Adejoro (2005), Ewulo et al. (2008) and Ayeni et al. (2010). 


\section{Effect of mineral fertilization:}

Regarding to the effect of NPK-fertilization on vegetative growth parameters of tomato plants, data in Table 3 indicated that the mean values of parameters under study were significantly increased with increasing NPK from 0 up to $50 \%$ of the recommended dose during both seasons. The highest values in the first season were 86.57, 98.32, 7.72, 690.26 and 74.56 were realized for the plants treated with NPK fertilizers at the rate of $50 \%$ from $\mathrm{RD}$ as compared with $67.62,88.03,5.17,467.77$ and 63.05 for plant height, number of leaves and branches/plant, fresh and dry weight, respectively. This may be due to the important role of $\mathrm{N}$ in plants. $\mathrm{N}$ is found in proteins , nucleic acids and co-enzymes, phosphorus also has a role in $\mathrm{N}_{2}$ fixation, enhance nodulation of plant and increase photosynthesis of plant, while potassium activates some enzymes and $\mathrm{K}^{+}$ions which play an important role in control stomata guard cells of leaves and as well increase photosynthesis (Abd-El- Aal,1990 and Said, 1997). The same trend was true during the second season. The result is in agreement with those of Baddour (2010), Muhammed et al. (2011) and lqbal et al.(2011) on tomato.

\section{Effect of foliar application:}

It is clear from the data presented in Table 3 that the effect of foliar application treatments of seaweed and yeast extract on all growth parameters was significant as compared to the untreated plants. Data clearly show that the highest significant values of the aformentioned parameters were recorded with spraying plants by seaweed extract $(2.5 \mathrm{ml} / \mathrm{L}$.) followed by spraying yeast extract $(5 \mathrm{~g} / \mathrm{L}$.). These increases were true and statistical in the two seasons of the experiment. The increases in vegetative growth parameters that obtained by spraying seaweed extract might be attributed to the hormonal activity of seaweed extract and presence of macro and micronutrients, i.e., $\mathrm{N}, \mathrm{K}_{2} \mathrm{O}, \mathrm{S}, \mathrm{Mg}, \mathrm{Ca}, \mathrm{B}, \mathrm{Fe}, \mathrm{Mn}, \mathrm{Cu}$, and $\mathrm{Zn}$. Spraying of seaweed extract has already shown to enhance plant growth by El-Afifi et al. (2009) on squash, Bhat et al., (2010) on sweet pepper and Nour et al. (2010) reported that spraying tomato hybrids with seaweed extracts at the rate of $1 \mathrm{~g} / \mathrm{L}$ recorded maximum values of plant growth characters. The increases in plant growth due to spraying yeast extract may be attributed to the role of yeast, which contains growth factors and a relatively larger proportion of cytokinins, free amino acids and short peptides of two or three amino acids long than protein hydrolisates, several vitamins as well as nutritional elements ( $\mathrm{Na}, \mathrm{Ca}, \mathrm{Fe}, \mathrm{Mg}, \mathrm{K}, \mathrm{P}, \mathrm{S}, \mathrm{Zn} \& \mathrm{Si}$ ) and organic compound which have an important role and stimulative effect on cell division and enlargement traits ( Khedr \& Farid ,2000). Similar result were mentioned by Abou-Aly (2005) on tomato, El-Tohamy et al. (2008) on eggplants, El-Sayed et al. (2010) and Abou El-Yazied and Mady (2011) on tomato plants. 
Table 3: Vegetative growth parameters of tomato plant at 75 (DAT*) as affected by chicken manure $\left(\mathrm{Ch} \mathrm{M}^{\star}\right)+$ bio mixture ${ }^{\star \star}$, mineral fertilization and foliar application treatments during seasons of 2009 and 2010.

\begin{tabular}{|c|c|c|c|c|c|c|c|c|c|c|}
\hline \multicolumn{2}{|c|}{$\begin{array}{l}\text { Dry weight } \\
\text { (g) }\end{array}$} & \multicolumn{2}{|c|}{$\begin{array}{c}\text { Fresh weight } \\
\text { (g) }\end{array}$} & \multicolumn{2}{|c|}{$\begin{array}{c}\text { No. of } \\
\text { branches/plant }\end{array}$} & \multicolumn{2}{|c|}{$\begin{array}{c}\text { No. of } \\
\text { leaves/plant }\end{array}$} & \multirow{2}{*}{\multicolumn{3}{|c|}{\begin{tabular}{|l|l|l}
$\begin{array}{l}\text { Plant height } \\
\text { (cm) }\end{array}$ & Char. \\
$2^{\text {nd }} \mid 1^{\text {st }}$ & Treatments. \\
\end{tabular}}} \\
\hline $2^{\text {nd }}$ & $1^{\text {st }}$ & $2^{\text {nd }}$ & $1^{\text {st }}$ & $2^{\text {nd }}$ & $1^{\text {st }}$ & $2^{\text {nd }}$ & $1^{\text {st }}$ & & & \\
\hline \multicolumn{11}{|c|}{ A:chicken manure + bio mixture ${ }^{\star \star \star}$} \\
\hline 65.22 & 65.24 & 574.30 & 564.25 & 6.39 & 6.22 & 88.16 & 89.25 & 77.97 & 75.93 & $\begin{array}{lrr}\text { Ch. } M^{*} & \text { at } & 3 \\
\text { ton/fed. } & (65 & \mathrm{Kg} . \\
\mathrm{N}) & & \end{array}$ \\
\hline 71.90 & 72.99 & 603.77 & 593.78 & 6.80 & 6.67 & 94.67 & 97.10 & 79.83 & 78.25 & $\begin{array}{lcr}\text { Ch.M } & \text { at } & 6 \\
\text { ton/fed. } & (130 & \mathrm{Kg} \\
\mathrm{N}) & \end{array}$ \\
\hline * & * & * & * & * & N.S & * & * & * & * & F.test \\
\hline \multicolumn{11}{|c|}{ B: NPK levels } \\
\hline 63.06 & 63.05 & 475.30 & 467.77 & 5.29 & 5.17 & 86.88 & 88.03 & 69.20 & 67.62 & Wit \\
\hline 74.06 & 74.56 & 702.77 & 690.26 & 7.91 & 7.72 & 95.96 & 98.32 & 88.60 & 86.57 & $50^{\circ}$ \\
\hline$*$ & * & * & * & * & * & * & * & * & * & F.te \\
\hline \multicolumn{11}{|c|}{ C:Foliar application } \\
\hline 61.32 & 64.45 & 544.53 & 534.89 & 5.93 & 5.83 & 85.00 & 86.58 & 74.49 & 73.23 & $\begin{array}{l}\text { Without } \\
\text { water) }\end{array}$ \\
\hline 66.18 & 64.45 & 644.50 & 636.84 & 7.45 & 7.25 & 101.25 & 103.98 & 84.54 & 82.30 & Sea \\
\hline 78.18 & 78.60 & 578.07 & 565.31 & 6.41 & 6.25 & 88.01 & 88.98 & 77.68 & 75.75 & Yeast \\
\hline 0.67 & 0.59 & 4.96 & 4.86 & 0.05 & 1.14 & 0.85 & 0.86 & 0.71 & 0.69 & LSD $_{\text {at } 5 \%}$ \\
\hline & & & & & & & & & & \\
\hline
\end{tabular}

\section{Effect of triple interaction:}

The interaction effects among chicken manure +bio mixture, mineral fertilization and foliar applications on plant growth parameters under study were presented in Table 4. It could be observed that the mean values of vegetative parameters above were significantly affected by the different applications except number of branches in the $1^{\text {st }}$ season. The highest mean values were recorded with adding chicken manure at 6 ton/fed. + bio mixture with $50 \%$ NPK from RD in presence of spraying seaweed extract which were $92.20,114.70,9.00,748.16$ and 78.11 for plant height, number of leaves and branches/plant, fresh and dry weight of tomato plants in the $1^{\text {st }}$ season, respectively. The same trend was obtained in the $2^{\text {nd }}$ season, similar results on tomato plants were obtained by Patil et al. (2004), Bayoumi (2005), Jagadeesha (2008), Mahila et al. (2010). Also, Dawa et al. (2012) on pepper plant found that foliar application of seaweed extract with chicken manure as a source of organic fertilization in presence of bio fertilizers enhanced vegetative plant growth, N, P and K percentages in leaves. Khan et al. (2012) reported that biofertilizers (Azotobacter+ Azospirillum) combined with organic fertilizer+ $100 \%$ recommended $\mathrm{N}$ gave the highest values of plant height and 
Dawa, Kawsar k. A. et al.

number of leaves of pepper plants than using organic or bio-fertilizers alone.

Table 4: Interaction effect of chicken manure $\left(\mathrm{Ch}_{\mathrm{M}} \mathrm{M}^{\star}\right)+$ bio mixture ${ }^{\star \star}$, mineral fertilization and foliar application treatments on vegetative growth parameters of tomato plant during 2009 and 2010 seasons.

\begin{tabular}{|c|c|c|c|c|c|c|c|c|c|c|c|c|}
\hline \multicolumn{2}{|c|}{$\begin{array}{c}\text { Dry weight } \\
(\mathrm{g})\end{array}$} & \multicolumn{2}{|c|}{$\begin{array}{c}\text { Fresh weight } \\
\text { (g) }\end{array}$} & \multicolumn{2}{|c|}{$\begin{array}{c}\text { No. of } \\
\text { branches/plant }\end{array}$} & \multicolumn{2}{|c|}{$\begin{array}{c}\text { No. of } \\
\text { leaves/plant }\end{array}$} & \multicolumn{2}{|c|}{$\begin{array}{l}\text { Plant } \\
\text { height } \\
(\mathbf{c m})\end{array}$} & \multirow{2}{*}{\multicolumn{3}{|c|}{ Treatments. Char. }} \\
\hline $2^{\text {nd }}$ & $1^{\text {st }}$ & $2^{\text {nd }}$ & $1^{\text {st }}$ & $2^{\text {nd }}$ & $1^{\text {st }}$ & $2^{\text {nd }}$ & $1^{\text {st }}$ & $2^{\text {nd }}$ & $1^{\text {st }}$ & & & \\
\hline 55.81 & 54.72 & 458.72 & 454.18 & 5.10 & 5.00 & 84.77 & 86.50 & 67.63 & 66.30 & 0Without & & Ch.M* \\
\hline 6.36 & 54.72 & 526.25 & 515.93 & 5.49 & 5.33 & 88.51 & 92.20 & 73.75 & 71.60 & 0 Seaweed & & \\
\hline 64.02 & 62.16 & 396.59 & 385.04 & 4.46 & 4.33 & 82.62 & 81.00 & 62.52 & 60.70 & 0 Yeast & & \\
\hline 47.32 & 46.39 & 625.37 & 619.18 & 6.80 & 6.67 & 97.44 & 101.50 & 81.91 & 80.30 & OWithout & & $\mathrm{n} / \mathrm{fe}$ \\
\hline 76.84 & 74.60 & 740.30 & 732.97 & 8.93 & 8.67 & 108.86 & 113.40 & 93.22 & 90.50 & 0Seaweed & & $(65 \mathrm{Kg}$. \\
\hline 90.96 & 88.31 & 698.54 & 678.19 & 7.55 & 7.33 & 105.84 & 108.00 & 88.79 & 86.20 & 0 Yeast & & \\
\hline 83.34 & 81.71 & 426.27 & \begin{tabular}{|l|}
417.91 \\
\end{tabular} & 4.76 & 4.67 & 85.59 & 83.10 & 64.57 & 63.30 & OWithout & & Ch.M* \\
\hline 51.86 & 50.35 & 555.79 & 550.29 & 6.18 & 6.00 & \begin{tabular}{|l|}
91.78 \\
\end{tabular} & 95.60 & 77.15 & 74.90 & 0Seaweed & & at \\
\hline 66.96 & 66.30 & 488.1 & 883.31 & 5.73 & 5.67 & 88.00 & 89.80 & 69.59 & 68.90 & $0 Y e^{2}$ & & 6 \\
\hline 58.81 & 58.23 & 667.76 & 648.31 & 7.07 & 7.00 & 72.19 & 75.20 & 83.83 & 83.00 & 0Without & & ton/fed. \\
\hline 79.67 & 78.11 & 755.64 & 748.16 & 9.18 & 9.00 & 115.85 & 114.70 & 94.04 & 92.20 & 0 Seaweed & & $(130 \mathrm{Kg}$ \\
\hline 90.77 & 88.13 & 729.00 & 714.71 & 7.90 & 7.67 & 75.56 & 77.10 & 89.82 & 87.20 & 0 Yeast & & \\
\hline 1.33 & 1.17 & 9.92 & 9.73 & 0.11 & N.S & 1.70 & 1.72 & 1.41 & 1.38 & 8 LSD $_{\text {at } 5 \%}$ & & \\
\hline
\end{tabular}

\section{Chemical composition:}

Effect of chicken manure + bio mixture on Chlorophyll:

It is clear from the data in Table 5 that the mean values of chlorophyll $a, b$ and total in the leaves of tomato were significantly affected as a result of adding chicken manure + bio mixture in $\mathbf{1}^{\text {st }}$ season, while such effect doesn't reflect any significant differences between the values of chlorophyll $b$ and total in the leaves of tomato just in the $2^{\text {nd }}$ season. The highest values were recorded with adding chicken manure at 6 ton/fed. + bio mixture during both seasons of 2009 and 2010. The result was in agreement with El-Sherif (2006) who mentioned that the highest $\mathrm{N}$ and $\mathrm{K}$ as well as total chlorophyll in cucumber leaves grown in higher addition of compost (6 ton/fed.) compared to 2 and 4 ton/fed.

\section{Effect of mineral fertilization on Chlorophyll:}

Data in the same table also indicated that at $50 \%$ level of NPK fertilizers led to increasing significantly the average values of chlorophyll $a, b$ and total in the leaves of tomato over those obtained from the control treatment. In addition, the highest mean values for the previously mentioned traits were connected with the treatment of $50 \%$ RD that recorded 0.711 . $0.745,0.504-0.525$ and $1.215-1.270$ in the $1^{\text {st }} \& 2^{\text {nd }}$ seasons for chlorophyll a, b and total, respectively. The satisfactory effects of mineral application on the content of chlorophyll may be attributed to its prominent role in the chlorophyll pigment synthesis or chlorophyll molecule in the plant 
tissues. These findings are corresponding to those reported by Saif-El-Deen (2000) on sweet potato and Nabih (2002) on potato.

Table 5: Chlorophyll a, b and total chlorophyll $(\mathrm{mg} / \mathrm{g})$ of tomato leaves as affected by chicken manure $\left(C\right.$..$\left.M^{*}\right)+$ bio mixture ${ }^{\star}$, mineral fertilization and foliar application treatments during 2009 and 2010 seasons.

\begin{tabular}{|c|c|c|c|c|c|c|}
\hline \multicolumn{2}{|c|}{$\begin{array}{c}\text { Total chlorophyll } \\
(a+b)\end{array}$} & \multicolumn{2}{|c|}{$\begin{array}{c}\text { Chlorophyll b } \\
\text { (mg/g F W) }\end{array}$} & \multicolumn{2}{|c|}{$\begin{array}{c}\text { Chlorophyll a } \\
\text { (mg/g F W) }\end{array}$} & \multirow{2}{*}{ Treatments. Char. } \\
\hline $2^{\text {nd }}$ & $1^{\text {st }}$ & $2^{\text {nd }}$ & $1^{\text {st }}$ & $2^{\text {nd }}$ & $1^{\text {st }}$ & \\
\hline \multicolumn{7}{|c|}{ A:chicken manure + bio mixture ${ }^{\star \star}$} \\
\hline 1.171 & 1.121 & 0.480 & 0.461 & 0.691 & 0.660 & Ch.M* at 3 ton/fed. $(65 \mathrm{Kg} . \mathrm{N})$ \\
\hline 1.192 & 1.144 & 0.489 & 0.472 & 0.703 & 0.672 & Ch.M $M^{*}$ at 6 ton/fed. $(130 \mathrm{Kg} . \mathrm{N})$ \\
\hline N.S & $*$ & N.S & $*$ & * & * & F.test \\
\hline \multicolumn{7}{|c|}{ B: NPK levels } \\
\hline 1.093 & 1.049 & 0.444 & 0.429 & 0.649 & 0.621 & Without NPK \\
\hline 1.270 & 1.215 & 0.525 & 0.504 & 0.745 & 0.711 & $50 \% \mathrm{NPK}^{\star \star \star}$ \\
\hline * & * & * & * & * & * & F.test \\
\hline \multicolumn{7}{|c|}{ C:Foliar application } \\
\hline 1.131 & 1.095 & 0.465 & 0.449 & 0.665 & 0.646 & Without (tap water) \\
\hline 1.234 & 1.181 & 0.507 & 0.488 & 0.727 & 0.693 & Seaweed \\
\hline 1.180 & 1.122 & 0.481 & 0.462 & 0.699 & 0.660 & Yeast \\
\hline 0.013 & 0.005 & 0.006 & 0.004 & 0.008 & 0.004 & LSD at $5 \%$ \\
\hline $\begin{array}{l}\text { (Ch.M) } \\
\text { *bio mix }\end{array}$ & cken $\mathbf{m}$ & ure. & 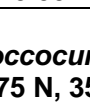 & . & rcui & and Bacillus me \\
\hline
\end{tabular}

\section{Effect of foliar application on Chlorophyll:}

Illustrated data in Table 5 show that spraying tomato plants with seaweed extract and yeast extract significantly increased chlorophyll a, b and total in the leaves of tomato comparing with the untreated plants. Data clearly show that the highest significant values of the mentioned parameters were recorded by spraying seaweed extract followed by yeast extract and finally untreated plants which recorded the lowest values. This trend was true during both seasons of 2009 and 2010. Regarding the effect of seaweed on chlorophyll, it might be due to that seaweed contain amounts of cytokinins, auxins and betaines, which enhance chlorophyll content in the leaves. Also this increase may be due to a decrease in chlorophyll degradation. Our finding in respect with Bhat et al., (2010) who showed that use of seaweed as an organic amendment increased the total chlorophyll content, and fruit yield in tomato, sweet pepper, and lettuce. Similarly, El-Tohamy and EL-Greadly (2007) found that application of yeast extract increased chlorophyll a and b as well as carotenoids in snap bean plants.

\section{Effect of triple interactions:}

The combination of chicken manure + bio mixture, NPK-fertilization and foliar applications show significant effect on chlorophyll $a, b$ and total chlorophyll in tomato leaves (Table 6). The average values of the parameters 
Dawa, Kawsar k. A. et al.

under study were significantly increased with all combinations of chicken manure + bio fertilizer, $50 \%$ NPK of RD. and foliar applications ( seaweed \& yeast). The highest mean values were recorded with seaweed extract $+50 \%$ NPK + chicken manure at 6 ton/fed. + bio mixture, while the lowest values were recorded with tap water + chicken manure at 3 ton/fed. + bio mixture in absence of NPK fertilization.

Table 6: Interaction effect of chicken manure $\left(\mathrm{Ch}_{.} \mathrm{M}^{\star}\right)+$ bio mixture*, mineral fertilization and foliar application treatments on chlorophyll a, b and total of tomato leaves during 2009 and 2010 seasons.

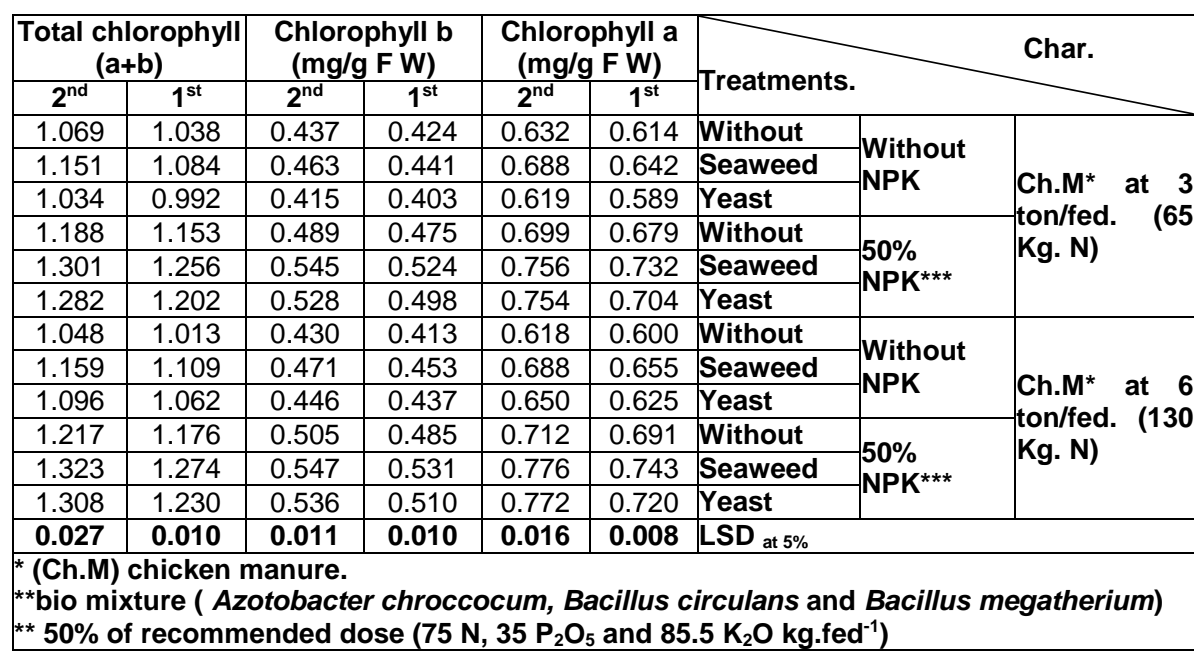

\section{Effect of chicken manure + bio mixture on $\mathrm{N}, \mathrm{P}$ and $\mathrm{K}$ percentages:}

Results in Table 7 show that adding of chicken manure + bio mixture in both years of the experiment increased the average values of $\mathrm{N}, \mathrm{P}$ and $\mathrm{K} \%$ in the leaves of tomato than those obtained for the untreated plants. The application of 6 ton/fed. from chicken manure + bio mixture gave the highest values of $\mathrm{N}, \mathrm{P}$ and $\mathrm{K}$ percentages as compared to 3 ton/fed. of chicken manure+ bio mixture. These results may be attributed to the roles of organic manures in soil properties which produce humus substances which improved the physical and chemical soil properties leading to increasing nutrients release availability, i.e., N, P and $\mathrm{K}$ uptake. Moreover, incorporation of organic material in soils can further increase NPK availability by increasing $\mathrm{CO}_{2}$ forming $\mathrm{H}_{2} \mathrm{CO}_{3}$ in the soil solution. Rizk (2002) on egg-plants found that plants which supplied by nitrogen in chicken manure forms significantly increased $\mathrm{N}$ and $\mathrm{K}$ content compared with cattle manure forms. The increase was also reported by Ewulo et al. (2008) and Ayeni et al. (2010) in tomato plants. 
Table 7: N, $\mathrm{P}$ and $\mathrm{K}$ percentages of tomato leaves as affected by chicken manure $\left(C \cdot M^{\star}\right)+$ bio mixture ${ }^{\star \star}$, mineral fertilization and foliar application treatments during 2009 and 2010 seasons.

\begin{tabular}{|c|c|c|c|c|c|c|}
\hline \multicolumn{6}{|c|}{ Leaves } & \multirow{3}{*}{ Treatments. } \\
\hline \multicolumn{2}{|c|}{ K\% } & \multicolumn{2}{|c|}{$\mathbf{P} \%$} & \multicolumn{2}{|c|}{ N\% } & \\
\hline $2^{\text {nd }}$ & $1^{\text {st }}$ & $2^{\text {nd }}$ & $1^{\text {st }}$ & $2^{\text {nd }}$ & $1^{\text {st }}$ & \\
\hline \multicolumn{7}{|c|}{ A:chicken manure + bio mixture ${ }^{\star \star}$} \\
\hline 2.24 & 2.20 & 0.513 & 0.490 & 2.31 & 2.21 & Ch. $M^{\star}$ at 3 ton/fed. (65 Kg. N) \\
\hline 2.28 & 2.24 & 0.523 & 0.501 & 2.35 & 2.26 & Ch. $M^{\star}$ at 6 ton/fed. (130 Kg. N) \\
\hline * & * & N.S & * & * & N.S & F.test \\
\hline \multicolumn{7}{|c|}{ B: NPK levels } \\
\hline 2.08 & 2.05 & 0.470 & 0.449 & 2.08 & 2.00 & Without NPK \\
\hline 2.43 & 2.39 & 0.567 & 0.542 & 2.58 & 2.47 & $50 \%$ NPK $^{\star \star \star}$ \\
\hline${ }^{*}$ & ${ }^{*}$ & ${ }^{*}$ & ${ }^{*}$ & ${ }^{*}$ & ${ }^{*}$ & F.test \\
\hline \multicolumn{7}{|c|}{ C:Foliar application } \\
\hline 2.18 & 2.14 & 0.491 & 0.476 & 2.23 & 2.15 & Without (tap water) \\
\hline 2.36 & 2.33 & 0.546 & 0.521 & 2.46 & 2.36 & Seaweed \\
\hline 2.24 & 2.19 & 0.518 & 0.489 & 2.30 & 2.21 & Yeast \\
\hline 0.02 & 0.03 & 0.006 & 0.004 & 0.03 & 0.04 & LSD at $5 \%$ \\
\hline (Ch.M) & ren $\mathbf{m}$ & & & $2-$ & & 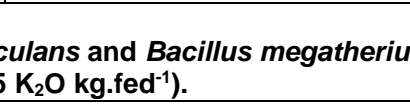 \\
\hline
\end{tabular}

\section{Effect of mineral fertilization on $\mathrm{N}, \mathrm{P}$ and $\mathrm{K}$ percentages:}

The different comparisons tabulated in Table 7 indicated that increasing NPK- applied level from 0 to $50 \%$ RD significantly increased N, P and $\mathrm{K} \%$ in the leaves of tomato. The highest mean values for the previously mentioned traits were found to be associated with the addition of $50 \%$ RDNPK and recorded in the $1^{\text {st }}$ season as $2.47,0.542 \& 2.39 \%$ in the leaves of tomato for $\mathrm{N}, \mathrm{P}$ and $\mathrm{K} \%$, respectively. The same trend was true in the $2^{\text {nd }}$ season. These results may be owed to the important role of NPK elements on improving root growth, hence increasing the absorbing area of root. Similar result was reported by Baddour (2010) who stated that increasing NPKapplied level from 50 to $75 \%$ and to $100 \%$ RD significantly increased N, P and $\mathrm{K} \%$ in the leaves of tomato plants.

\section{Effect of foliar application on N, P and K percentages:}

Regarding the effect of spraying tomato plants with seaweed and yeast extract, data in Table 7 indicated that there is a significant effect on $\mathrm{N}$, $\mathrm{P}$ and $\mathrm{K}$ percentages in leaves of tomato compared with the untreated plants during both seasons of 2009 and 2010. Data clearly showed that the highest significant values of $\mathrm{N}, \mathrm{P} \& \mathrm{~K}$ percentages were recorded with spraying seaweed extract followed by yeast extract. While the untreated plants recorded the lowest values of the mentioned chemical parameters in both seasons. Our finding connected with findings of Bhat et al. (2010) who showed that the use of seaweed as an organic amendment increased the total chlorophyll content in tomato. Also Hamed (1997), El-Aidy et al. (2002) and Dawa et al.(2012) they indictaed that foliar application with seaweed extract increased N, P and K percentages in sweet pepper leaves. 


\section{Effect of triple interaction:}

It is evident from the data presented in Table 8 that the average values of $\mathrm{N}, \mathrm{P}$ and $\mathrm{K}$ percentages in the leaves of tomato plants were significantly affected as a result of the combinations between the rates of chicken manure + bio mixture, NPK-applied and the treatments of foliar application. In this respect, using of NPK fertilization in the presence of poultry manure + bio mixture with seaweed or yeast extract was superior for increasing the mean values of $\mathrm{N}, \mathrm{P}$ and $\mathrm{K}$ percentages in the leaves of tomato. The highest mean values of $\mathrm{N}, \mathrm{P}$ and $\mathrm{K}$ percentages in the leaves of tomato were be associated with the treatment of chicken manure at 6 ton/fed. + bio mixture with $50 \%$ NPK from RD and spraying with seaweed extract.

Table 8: Interaction effect of chicken manure $\left(\mathrm{Ch} \mathrm{M}^{\star}\right)+$ bio mixture ${ }^{\star \star}$, mineral fertilization and foliar application treatments on $\mathrm{N}, \mathrm{P}$ and $\mathrm{K} \%$ of tomato leaves during 2009 and 2010 seasons.

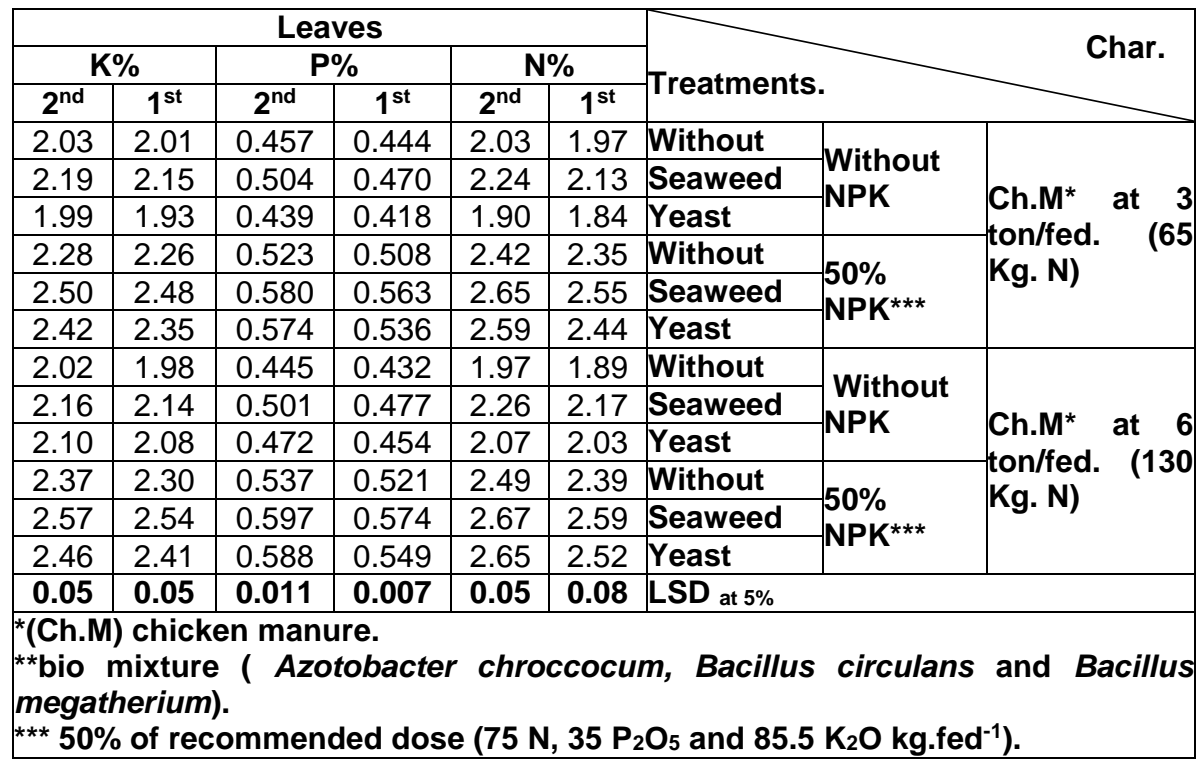

\section{CONCLUSION}

It is concluded from the present findings that tomato plants received chicken manure at 6 ton/fed. $(130 \mathrm{Kg} . \mathrm{N})+$ bio mixture, $50 \% \mathrm{NPK}$ from recommended dose, i.e., $75 \mathrm{~N}, 35 \mathrm{P}_{2} \mathrm{O}_{5}$ and $85.5 \mathrm{~K}_{2} \mathrm{O} \mathrm{kg.fed}-1$ and sprayed with seaweed extract at the rate of $2.5 \mathrm{~m} / \mathrm{l}$ recorded the highest values of vegetative growth parameters, chlorophyll and N,Pand $\mathrm{K}$ percentages in tomato leaves under the same condition of the study. 


\section{REFERENCES}

Abd EL- Aal, M. S. (1990). Effect of nitrogen, phosphorus and potassium fertilization on the productivity of fodder beet. Egypt. J. of Agron., 15 (12): 159- 170.

Abou El-Yazied, A. and M. A. Mady (2011). Effect of Naphthalene Acetic Acid and Yeast Extract on Growth and Productivity of Tomato (Lycopersicon esculentum Mill.) Plants. Res. J. Agric. \& Biol. Sci., 7(2): 271-281.

Abou-Aly, H. A. (2005). Stimulatory effect of some yeast application on response of tomato plants to inoculation with biofertilizeres. Annals. Sci. Moshtohor., 43(2): 595-609.

Adenawoola, A. R. and S. A. Adejoro (2005). Residual effects of poultry manure and NPK fertilizer residues on soil nutrients and performance of Jute (Corchorus olitorus L) Nigerian J. Soil Scie., 15:133-135. (6)

Ayeni, L. S.; T. O. Omole, E. O. Adeleye and S. O. Ojeniyi (2010).Integrated Application of Poultry Manure and NPK Fertilizer on Performance of Tomato in Derived Savannah Transition Zone of Southwest Nigeria, [Nature and Science. 2010;8(2):50-54]. (ISSN: 1545-0740).

Baddour, A. G. (2010). Effect of bio-fertilization on growth and productivity of tomato plant. M.Sc. Thesis. Fac. Agric. Mansoura. Univ., Egypt.

Bayoumi, Y. A. (2005). Studies on organic production of tomato crop. Ph.D. Thesis, Fac. Agric. Ain Shams Univ., Egypt.

Bhat, N. R.; M. Albaho, M. K. Suleiman, S. Al-Dosery, G. Al-Essa, R. AlNafisi, T. Al-Ati, B. Thomas, S. Isath Ali, P. George, R. Bellen, and M. Al-Zalzaleh (2010). "Optimization and Pilot Scale Greenhouse Organic Vegetable Production". Kuwait Institute for Scientific Research, Report No. KISR 10272, Kuwait.

Black, C. A. (1965). Methods of soil analysis. Part 2. Amer. Soci. of Agric. [NC] Publisher, Madison, Wisconsin.

Chapman, H.D. and F. Pratt (1961). "Methods Of Soil Analysis". Part 2 A.S.S. Madison wiscoasin.course" Puble. By the auther, Dept. of Soils, Univ. of Wise., Madison 6, Wishensin, U.S.A.

Dawa, K. K. ; H. M. E. Abd El - Nabi and W. E. Swelam (2012). Response of sweet peper plants (vegetative growth and leaf chemical constituents) to organic, bio fertilizers and some foliar application treatments, J. Plant Production, Mansoura, Univ., Vol. 3 (9): 2465 - 2478, 2012.

El-Afifi, S. T.; E. A. A. Tartoua and S. M. Shabana (2009). Effect of some different sources and rates of organic manure of summer squash yield production. J. Agric. Sci. Mansoura. Univ., 34 (3): 1757-1780.

El-Aidy, F.; A. I. El-Zawily B. I. El-Sawy and E. M. Hamed (2002). Effect of seaweed extract on sweet pepper plants grown under protected cultivation. $2^{\text {nd }}$ Inter. Conf. Hort. Sci., 10-12 sept. Kafr El-shekh, Tanta Univ., Egypt. 
El-Said, M. E. (2009). A comparative study for impact of low phosphorus fertilization in different combination with sulpher, Gypsum and phosphoren on tomato growth, mineral status and productivity.J. Agric. Sci., Mansoura. Univ., 34(5): 4829-4840.

El-Sayed, A.; M. M. B. Shokr and M. A. A. El-Sherbini (2010). Some agronomical practices for improving tomato (lycopersicon esculentum Mill) productivity under high temperature conditions. J. Plant Production, Mansoura. Univ., 1 (9): 1283-1297.

El-Sherif, M. F. A. (2006). Growth and yield of cucumber as influenced by compost and nitrogen fertilizer in sandy soil using nuclear technique for determination of nitrogen. Ph.D. Thesis, Fac. Agric. Ain Shams Univ., Egypt.

El-Tohamy, W. A. and N. H. M. El-Greadly (2007). Physiological responses, growth, yield and quality of snap beans in response to foliar application of yeast, vitamin $\mathrm{E}$ and zinc under sandy soil conditions. Australian Journal of Basic and Applied Sciences, 1(3): 294-299.

El-Tohamy, W. A.; H. M. El-Abagy and N. H. M. El-Greadly (2008).Studies on the Effect of Putrescine, Yeast and Vitamin C on Growth, Yield and Physiological Responses of Eggplant (Solanum melongena L.) Under Sandy Soil Conditions. Australian. J. Agric. \& Biol. Sci., 2(2): 296-300.

Ewulo, B. S., S. O. Ojeniyi and D. A.Akanni (2008). Effect of poultry manure on selected soil physical and chemical properties, growth, yield and nutrient status of tomato .African J. Agric. Res. 3(9): 612-616

Fawzy, Z. f.; E. M. El-Bassiony and S. A. Saleh (2007). Effect of chemical fertilizer, pultry manure and biofertilizer on growth yield and chemical contents of tomato plants. J. Agric. Sci. Mansoura. Univ., 32 (8): 65836594.

Gomez, K. A. and A. A. Gomez (1984). "Statistical Procedures for Agricultural Research". John Wiley and Sons, Inc., New York.pp:680.

Goodwine, T. W. (1965). Quantitative analysis of the chloroplast pigments. Academic Press, London and New York., 12: 427- 506.

Hamed, E. M. (1997). Studies on seaweed extracts and shoot pruning on sweet pepper under plastic green house. M.Sc. Thesis, Fac. Agric. Tanta Univ., Egypt.

Iqbal, M.;M.Niamatullah, I. Yousaf, M. Muinr and M. Z. Khan (2011). Effect of nitrogen and potassium on growth, economical yield and yield components of tomato.Sarhad J. Agric., 27 (4): 545-548.

Jackson, M. L. (1967). "Soil Chemical Analysis Advanced Course" Puble. By the auther, Dept. of Soils, Univ. of Wise., Madison 6, Wishensin, U S A.

Jagadeesha, V. (2008). Effect of organic manures and biofertilizers on growth, seed yield and quality in tomato (Lycopersicon esculentum Mill.) Cv. Megha.M. S.c. Thesis.Univ. Agric. Sci., Dharwad. Karnataka, India.

Khan, Z.; S. A. Tiyagi, I. Mohamood and R. Rizvi (2012). Effect of Nfertilization, organic matter and biofertilizers on growth and yield of chilli in relation to management of plant-parastic nematods. Turk. J. Bot. 36: 73-81. 
Khedr, Z. M. A. and S. Farid (2000). Response of naturally virus infected tomato plants to yeast extract and phosphoric acid application. Annals Agric. Sci. Moshtohor, 38 (2): 927-939.

Mahato, P., A. Badoni and J. S. Chauhan (2009). Effect of Azotobacter and Nitrogen on Seed Germination and Early Seedling Growth in Tomato. Department of Seed Sci. and Tech; 1 (4): 62-66.

Mahila, P. G. Mahavidhyalaya and Jodhpur (2010). Growth and Productivity of Tomato (Lycopersicon esculentum Mill.) Grown in Greenhouse as affected by Organic, Mineral and Bio-N-Fertilisers.Sci. \& Cult. 76 (3-4) 128-131.

Malak, A.E. R.; A.M. El-Bassiony and Hoda A.M. (2008). Behaviour of some micronutrients in soil and tomato plant organs under different levels and types of fertilizers, Australian Journal of Basic and Applied Sciences, 2(2): 288-295.

Nabih, M. A. (2002). Studies on potatoes (solanum tuberosum L.). M. Sc. Thesis, Fac. of Agric. Mans. Univ., Egypt.

Nour, K. A. M.; N. T. S. Mansour and W. M. Abd El-Hakim (2010). Influence of foliar spray with seaweed extract on growth, setting and yield of tomato during summer season. J. Plant Production, Mansoura. Univ., 1 (7): 961-976.

Patil, M. B., R. G. Mohammed and P. M. Ghadge (2004). Effect of organic and inorganic fertilizers on growth, yield and quality of tomato. J. Maharashtra Agric. Univ. 29(2): 124-127.

Pregle, E. (1945). "Quantitative Organic Micro-Analysis" 4th Ed. J. Chudrial, London.

Rizk, F. A. (2002). Bioorganic and chemical fertilizer as affected the productivity of eggplant (solanum melongena L.). J. Agric. Sci. Mansoura. Univ., 27 (12): 8477-8491.

Said, Th.A. (1997). Effect of some fertilization treatments on yield and chemical composition of fodder beet at Ras Sudr region. M. Sc. Fac. of Agric., Ain Shams Univ. Egypt.

Saif -El-Din, U. Z. (2000). Studies on bio and chemical fertilization on sweet potato (Ipomoea batatas L.). M. Sc. Thesis, Fac. Agric. Mansoura. Univ., Egypt.

Togun, A. O. and W. B. Akanbi (2003). Comparative effectiveness of organicbased fertilizer to mineral fertilizer on tomato growth and fruit yield. Compost Sci. and Utilization; 11(4): 337-342

Turan M., N.Ataoglu and F. Sahin (2007). Evaluation of the capacity of phosphate solubilizing bacteria and fungi on different forms of phosphorus in liquid culture. J. Sustain. Agric., 28: 99-109. 
Dawa, Kawsar k. A. et al.

تأثثر التسميد بسماد الدواجن مختلط بالسـماد الحيوى، المعدنى وبعض معـاملات

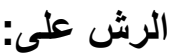

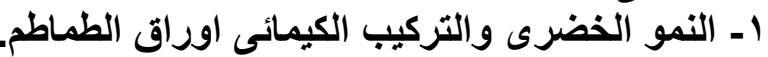

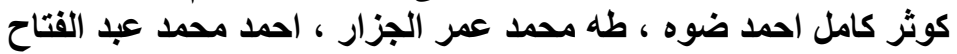

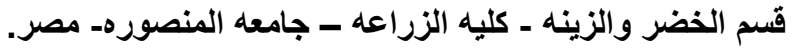

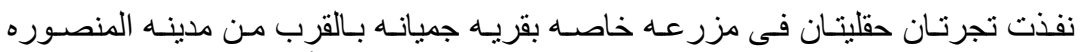

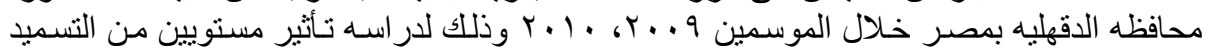

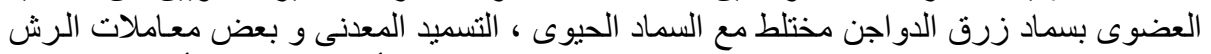

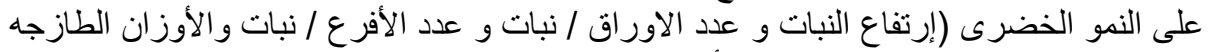

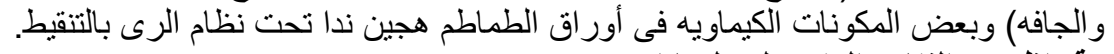
وقد اظهرت النتائج المتحصل عليهات الكيران:-

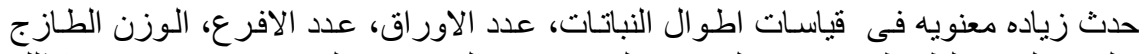

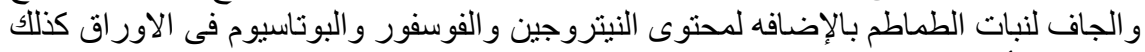

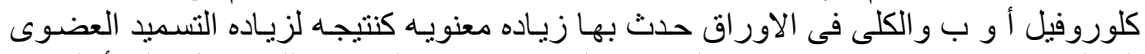

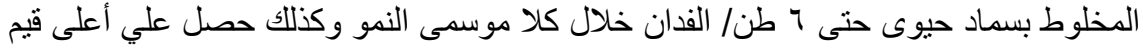

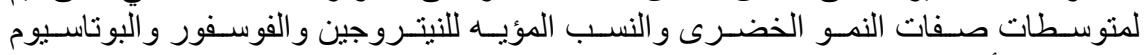

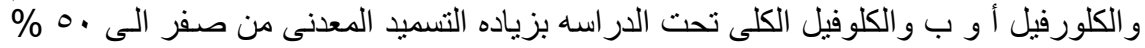
من الموصى به خلال الموسمين.

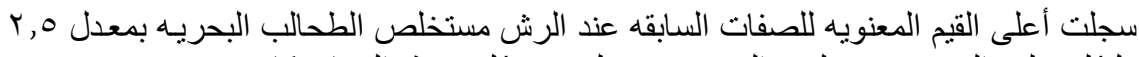

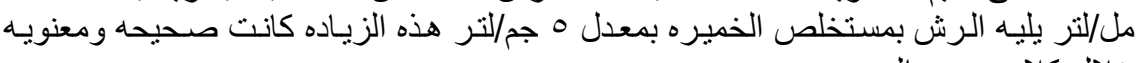

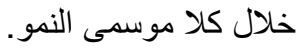

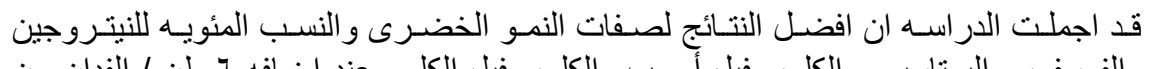

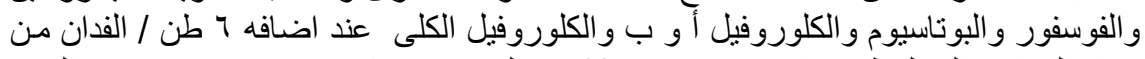

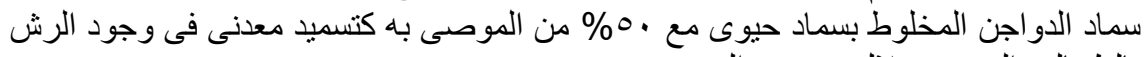
بالطحالب البحريه خلال موسمى النمو.

كلية الزراعة - جامعة المنصورة

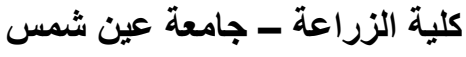

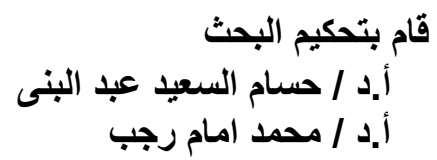

